University of Nebraska - Lincoln

DigitalCommons@University of Nebraska - Lincoln

Faculty Papers and Publications in Animal

Science

Animal Science Department

1980

\title{
Long-Term Effects of Dietary Additions of Alfalfa and Tallow on Sow Reproductive Performance
}

\author{
D. S. Pollmann \\ University of Nebraska-Lincoln \\ D. M. Danielson \\ University of Nebraska-Lincoln \\ M. A. Crenshaw \\ University of Nebraska-Lincoln \\ E. R. Peo, Jr. \\ University of Nebraska-Lincoln
}

Follow this and additional works at: https://digitalcommons.unl.edu/animalscifacpub

Part of the Animal Sciences Commons

Pollmann, D. S.; Danielson, D. M.; Crenshaw, M. A.; and Peo, Jr., E. R., "Long-Term Effects of Dietary Additions of Alfalfa and Tallow on Sow Reproductive Performance" (1980). Faculty Papers and Publications in Animal Science. 652.

https://digitalcommons.unl.edu/animalscifacpub/652

This Article is brought to you for free and open access by the Animal Science Department at DigitalCommons@University of Nebraska - Lincoln. It has been accepted for inclusion in Faculty Papers and Publications in Animal Science by an authorized administrator of DigitalCommons@University of Nebraska - Lincoln. 


\title{
LONG-TERM EFFECTS OF DIETARY ADDITIONS OF ALFALFA AND TALLOW ON SOW REPRODUCTIVE PERFORMANCE ${ }^{1}$
}

\author{
D. S. Pollmann, D. M. Danielson, M. A. Crenshaw and E. R. Peo, Jr. ${ }^{2}$ \\ University of Nebraska, Nortb Platte 69101
}

\begin{abstract}
Summary
Eighty-eight crossbred sows were used to evaluate the effects of including sun-cured alfalfa in gestation diets and tallow in lactation diets on reproductive performance for three successive reproductive cycles. Two pelleted gestation diets were fed: (1) no alfalfa and (2) $50 \%$ alfalfa. Both diets were fed at the rate of $6,000 \mathrm{kcal}$ of $\mathrm{ME} / \mathrm{head} / \mathrm{day}$ for the first 90 days of gestation. Two lactation diets were fed, one containing no added tallow and the other $8 \%$ stabilized tallow. Lactation diets were initiated at approximately 90 days of gestation and fed at a rate of $2.72 \mathrm{~kg} / \mathrm{head} / \mathrm{day}$ until farrowing and offered ad libitum postpartum. A higher percentage of the sows fed the alfalfa treatment completed the three gestation-lactation cycles than did those fed the control diet. Although total pigs farrowed per litter did not differ significantly between treatments, a reduction $(\mathrm{P}<.05)$ in average birth weight was observed for the alfalfa-fed group. The number of pigs alive at 14 days was higher for the alfalfa-fed group $(\mathrm{P}<.05)$. Survival rate pooled over the three reproductive cycles was approximately $8 \%$ higher for sows fed alfalfa; the addition of tallow did not significantly improve survival rate. Sows fed alfalfa diets gained less $(\mathrm{P}<.05)$ during gestation than controls, but lactation diets did not affect maternal weight gains. Sows fed the tallow lactation diet consumed $6.8 \%$ less feed than the controls $(P<.05)$, but total energy intake for both diets was similar.
\end{abstract}

(Key Words: Alfalfa, Tallow, Gestation, Lactation, Reproductive Performance, Baby Pig Survival Rate.)

\footnotetext{
${ }^{1}$ Published as paper no. 5869, Journal Series, Nebraska Agr. Exp. Sta.

${ }^{2}$ Dept. of Anim. Sci. Acknowledgment is made to Debbie Koester and Alice Teter for their assistance in preparation of the manuscript.
}

Two important ways of increasing economic efficiency in pork production are to reduce breeding herd feed costs and to improve neonatal survival rate. It has been suggested that substituting alfalfa in the diets of dry and gestating sows can reduce feed cost without adversely affecting reproductive performance (Peo, 1975). Several researchers (Teague, 1955; Seerley and Wahlstrom, 1963 ; Danielson and Noonan, 1975; Allee, 1977; Pollmann and Danielson, 1978) have observed that high levels of alfalfa did not significantly affect reproductive performance.

Recently, researchers have investigated the addition of fat to. sow diets to determine its influence on neonatal survival rate. Seerley et al. (1974) observed that addition of corn oil to the diet from gestation day 109 through lactation increased survival rate of the pigs weighing less than $1,000 \mathrm{~g}$ at birth. Boyd et al. (1978), who introduced a $20 \%$ tallow lactation diet on gestation day 100 , observed a slight increase in survi$\mathrm{val}$ rate and an increase in fat content of colostrum. In another study, Boyd et al. (1979) found that adding $8 \%$ tallow to the sow's diet increased both total solids and fat content of the milk.

Although alfalfa and tallow have each shown beneficial effects when offered as alternative feeds during the reproductive phase of swine production, the use of both in one maternal feeding regimen has not been investigated. The objective of this study was to determine the long-term effects of including alfalfa in gestation diets and tallow in lactation diets on reproductive performance of sows.

\section{Experimental Procedure}

Eighty-eight crossbred sows (second to fourth parity) were used to evaluate the effects of adding sun-cured alfalfa to gestation diets and tallow to lactation diets for three successive reproductive cycles. The sows were blocked on the parity number and then allotted at random 
to four dietary treatments (table 1). During gestation, the sows received either ( 1 ) a control diet of corn-soybean meal (C), or (2) the $50 \%$ alfalfa (A) diet. The pelleted gestation diets which were calculated to equalize daily nutrient intake, were individually fed in outside stalls at the rate of $6,000 \mathrm{kcal}$ of metabolizable energy/head/day (C, $1.95 \mathrm{~kg} ; \mathrm{A}, 2.36 \mathrm{~kg}$ ). Energy values used for the gestation diets were determined previously in sow metabolism studies (Pollman et al., 1979). Sows were introduced to the experimental gestation diets on the day of breeding.

The lactation diets offered were (1) a control, with no tallow (LC) and (2) an $8 \%$ tallow diet (LT), in which tallow replaced corn. Lactation diets were initiated on approximately day 90 of gestation and fed at a rate of 2.72 $\mathrm{kg} / \mathrm{head} /$ day until farrowing. The dietary sequences were: (1) CLC, (2) CLT, (3) ALC and (4) ALT.

The sows were weighed before breeding, at 90 days, and at 109 days postcoitum. Sows were moved into the farrowing house on approximately day 109 of gestation and were fed ad libitim postpartum.
The pigs were weighed at birth and on day 14 postpartum. No creep feed was given during the study, but the pigs had access to the sow's feed. Water was available ad libitum.

At approximately 3 weeks of age, the litters were weaned and the sows were weighed and moved from the farrowing house into holding pens that allowed fenceline contact with a boar for approximately 5 days. When signs of estrus were detected, the sows were returned to the original gestation diet and pen. All the sows were bred according to a pen mating system, with continual boar exposure for approximately 60 days postweaning. Physically disabled sows with conditions such as rectal or vaginal prolapses or lameness were culled. Sows that failed to save more than three pigs in the previous farrowing were also culled.

Data were analyzed by least-squares analysis of variance (Harvey, 1960). Contingency tables were used to evaluate the differences between treatments in number of sows farrowing (Conover, 1971).

Results and Discussion

The effects on sow productivity of the

TABLE 1. COMPOSITION OF DIETS

\begin{tabular}{|c|c|c|c|c|c|}
\hline \multirow[b]{2}{*}{ Ingredient, \% } & \multirow{2}{*}{$\begin{array}{l}\text { Internat'l } \\
\text { Ref. No. }\end{array}$} & \multicolumn{2}{|c|}{ Gestation $^{\mathrm{a}}$} & \multicolumn{2}{|c|}{ Lactation $^{\mathrm{b}}$} \\
\hline & & $\mathrm{C}$ & A & LC & LT \\
\hline Yellow corn, ground & $4-02-931$ & 76.94 & 35.97 & 54.71 & 46.71 \\
\hline Soybean meal & $5-04-604$ & 15.00 & 10.00 & 15.00 & 15.00 \\
\hline Alfalfa, S-C, MB & $1-00-063$ & 2.50 & 50.00 & 4.13 & 4.13 \\
\hline Salt iodized & $6-04-152$ & .50 & .50 & .50 & .50 \\
\hline Trace minerals ${ }^{c}$ & & .10 & .10 & .10 & .10 \\
\hline Vitamin premix & & $1.00^{\mathrm{d}}$ & $1.00^{\mathrm{e}}$ & $1.00^{f}$ & $1.00^{f}$ \\
\hline Dicalcium phosphate & 6-01-080 & 3.81 & $\ldots$ & 2.06 & 2.06 \\
\hline Monosodium phosphate & $6-04-288$ & $\ldots$ & 2.25 & $\ldots$ & $\ldots$ \\
\hline Limestone, ground & $6-02-632$ & .15 & .20 & $\ldots$ & $\ldots$ \\
\hline Whole oats, ground & 4-03-309 & $\ldots$ & $\ldots$ & 15.00 & 15.00 \\
\hline Wheat bran, dry milled & $4-05-190$ & $\ldots$ & $\ldots$ & 7.50 & 7.50 \\
\hline Tallow & 4-07-880 & $\ldots$ & $\ldots$ & $\ldots$ & 8.00 \\
\hline
\end{tabular}

${ }^{\mathrm{a}}$ Fed at $6,000 \mathrm{kcal} \mathrm{ME} / \mathrm{head} /$ day- $1.95 \mathrm{~kg}$ of C, $2.36 \mathrm{~kg}$ of $\mathrm{A}$.

${ }^{b}$ Initiated on day 90 of gestation; $2.72 \mathrm{~kg} / \mathrm{head} /$ day until farrowing; after farrowing, ad libitum.

${ }^{c}$ Provided per kilogram of diet: $200 \mathrm{mg} \mathrm{Zn,} 100 \mathrm{mg} \mathrm{Fe}, 54 \mathrm{mg} \mathrm{Mn}, 11 \mathrm{mg} \mathrm{Cu}, 1.0 \mathrm{mg}$ Co and $1.5 \mathrm{mg} \mathrm{I}$.

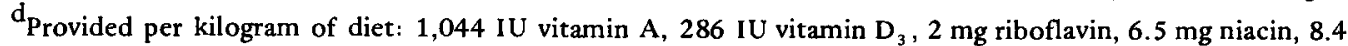
$\mathrm{mg}$ calcium pantothenate, $591 \mathrm{mg}$ choline chloride and $105.5 \mathrm{mcg}$ vitamin $B_{12}$

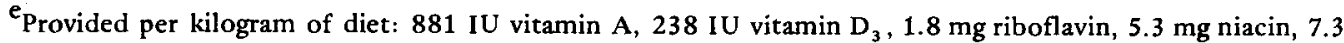
$\mathrm{mg}$ calcium pantothenate, $498 \mathrm{mg}$ choline chloride and $88.9 \mathrm{mcg}$ vitamin $\mathrm{B}_{12}$.

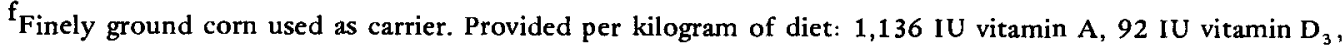
$2.3 \mathrm{mg}$ riboflavin, $8.2 \mathrm{mg}$ calcium pantothenate, $15.9 \mathrm{mg}$ choline chloride, $6.8 \mathrm{mg}$ niacin and $7.7 \mathrm{mcg}$ vitamin $\mathrm{B}_{12}$. 
dietary additions of alfalfa and tallow are summarized in table 2. A higher percentage of the sows fed the alfalfa treatment completed the three reproductive cycles than did those fed the control diet ( 89 vs $68 \%$ ). No significant differences were observed between treatments for the number of live pigs, stillborns or mummified fetuses. A significant reduction in birth weight was observed for pigs farrowed from sows in the alfalfa-fed group compared to those from sows fed the control diet (1.39 vs $1.47 \mathrm{~kg}$ ). Other researchers (Danielson and Noonan, 1975; Allee, 1977; Pollmann et al., 1978) have observed a similar decrease in birth weight with the addition of alfalfa to the gestation diet of the sow.

Although the average pig weight at 14 days was not affected by the treatments, the number of live pigs at 14 days was greater $(\mathrm{P}<.05)$ for sows fed alfalfa during gestation than for the controls. Survival rate, when pooled over the three reproductive cycles, was approximately $8 \%$ greater for sows fed alfalfa than for those fed the control diet $(78.1$ vs $70.2 \%)$. These results agree with those reported by Danielson and Noonan (1975), who observed that more pigs were weaned from sows receiving $25 \%$ alfalfa diets than from those fed no alfalfa $(9.7$ vs 7.9). The addition of tallow increased survival by about $2 \%$ ( 73.4 vs $75.6 \%$ ), although the difference was not significant. No significant alfalfa $x$ tallow interaction was observed, but the ALT group exhibited the best survival rate. These data suggest that feeding alfalfa through day 90 of gestation results in a greater improvement in pig survival than does feeding tallow from day 90 through lactation ( 8 vs $2 \%$ ).

Since more sows receiving the control diet

TABLE 2. EFFECT OF DIETARY ADDITIONS OF ALFALFA AND TALLOW ON SOW PRODUCTIVITY

\begin{tabular}{|c|c|c|c|c|c|c|c|}
\hline \multirow[b]{2}{*}{ Item } & \multirow{2}{*}{$\begin{array}{l}\text { Reproductive } \\
\text { Cycle }\end{array}$} & & \multicolumn{4}{|c|}{ Treatment ${ }^{\mathbf{a}}$} & \multirow[b]{2}{*}{$C V^{b}$} \\
\hline & & & CLC & CLT & ALC & $\overline{A L T}$ & \\
\hline \multicolumn{8}{|c|}{ No. litters } \\
\hline & 1 & & 21 & 20 & 22 & 22 & \\
\hline & 2 & & 18 & 18 & 21 & 21 & \\
\hline & 3 & & 14 & 14 & 19 & 20 & \\
\hline & & Total $^{\mathrm{c}}$ & 53 & 52 & 62 & 63 & \\
\hline \multicolumn{8}{|c|}{ No. live pigs } \\
\hline & 1 & & 10.5 & 11.7 & 11.0 & 11.0 & \\
\hline & 2 & & 10.7 & 11.7 & 11.4 & 11.7 & \\
\hline & 3 & & 11.3 & 11.1 & 13.2 & 11.2 & \\
\hline & & Avg & 10.8 & 11.6 & 11.8 & 11.3 & 21.2 \\
\hline \multicolumn{8}{|c|}{ Avg birth wt, $\mathrm{kg}$} \\
\hline & 1 & & 1.53 & 1.50 & 1.44 & 1.47 & \\
\hline & 2 & & 1.46 & 1.36 & 1.33 & 1.32 & \\
\hline & 3 & & 1.51 & 1.44 & 1.33 & 1.45 & \\
\hline & & Avged & 1.50 & 1.44 & 1.37 & 1.41 & 13.0 \\
\hline \multicolumn{8}{|c|}{ No. live at 14 days } \\
\hline & 1 & & 7.1 & 8.1 & 8.2 & 9.0 & \\
\hline & 2 & & 8.0 & 7.7 & 8.8 & 9.3 & \\
\hline & 3 & & 8.2 & 8.3 & 10.0 & 8.9 & \\
\hline & & $A v g^{C}$ & 7.7 & 8.0 & 8.9 & 9.1 & 28.2 \\
\hline \multicolumn{8}{|c|}{ Avg 14 day wt, $\mathrm{kg}$} \\
\hline & 1 & & 3.79 & 3.92 & 3.91 & 3.79 & \\
\hline & 2 & & 4.10 & 4.15 & 3.76 & 3.98 & \\
\hline & 3 & & 3.86 & 3.71 & 3.53 & 4.04 & \\
\hline & & Avg & 3.91 & 3.94 & 3.74 & 3.93 & 17.1 \\
\hline
\end{tabular}

\footnotetext{
${ }^{\mathrm{a}} \mathrm{CLC}=$ corn-soy gestation and corn-soy lactation; CLT $=$ corn-soy gestation and tallow lactation; ALC = alfalfa gestation and corn-soy lactation; $A L T=$ alfalfa gestation and tallow lactation.

${ }^{b} \mathrm{CV}=$ coefficient of variation based on pooled data.

$c_{\text {Alfalfa effect }}(\mathrm{P}<.05)$.

$\mathrm{d}_{\text {Time effect }}(\mathrm{P}<.05)$.
} 
TABLE 3. EFFECT OF ADDITIONS OF ALFALFA TO GESTATION DIETS ON SOW LONGEVITY

\begin{tabular}{lll}
\hline \hline & \multicolumn{2}{l}{ Gestation diet treatment } \\
\cline { 2 - 3 } Item & $\begin{array}{l}\text { Control } \\
\text { (corn-soy) }\end{array}$ & $\begin{array}{l}50 \% \\
\text { Alfalfa }\end{array}$ \\
\hline No. sows culled & $15(34.1 \%)^{\mathrm{a}}$ & $5(11.4 \%)$ \\
Reasons for culling: & & \\
Poor performance & 4 & 1 \\
Death & 3 & 1 \\
Prolapse & 2 & 1 \\
Physical abnormalities & 6 & 2 \\
\hline
\end{tabular}

${ }^{\text {a }}$ Percentage of sows failing to complete three gestations.

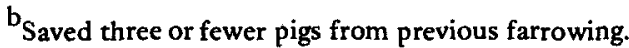

$\mathrm{c}_{\text {Feet, legs and vulva. }}$

failed to complete the three reproductive cycles $(\mathrm{P}<.05)$, it is apparent that sow longevity (table 3) was improved by diets containing alfalfa
(34.1 and 11.4\% culled from control and alfalfa groups, respectively). The reasons for culling were: (1) poor performance (saved three or fewer pigs from the previous farrowing), (2) death, (3) rectal or vaginal prolapse and (4) physical abnormalities of the feed, legs or vulva. The major reason for removal of sows on the control diet was physical abnormalities. Frobish et al. (1973) obtained similar results in a study of the long-term (three cycles) effect of energy intake on reproductive performance of swine. The authors concluded that the most pronounced effect of excessive energy $(7,500 \mathrm{kcal}$ $\mathrm{ME} /$ day) intake was increased number of animals culled because of leg abnormalities.

Up to gestation day 90 (table 4), the alfalfafed sows gained significantly less than the controls ( 16.8 vs $26.3 \mathrm{~kg}$ ). A significant gestation treatment $X$ cycle interaction was observed for gestation gain through day 90 (figure 1). During the first reproductive cycle, the sows fed the alfalfa treatment gained slightly more than the

TABLE 4. EFFECT OF DIETARY ADDITIONS OF ALFALFA AND TALLOW ON MATERNAL WEIGHT AND LACTATION FEED INTAKE

\begin{tabular}{|c|c|c|c|c|c|c|}
\hline \multirow[b]{3}{*}{ Item } & \multirow{3}{*}{$\begin{array}{l}\text { Reproductive } \\
\text { cycle }\end{array}$} & & \multicolumn{4}{|c|}{ Treatment } \\
\hline & & & \multicolumn{2}{|c|}{ Gestation } & \multicolumn{2}{|c|}{ Lactation } \\
\hline & & & Control & Alfalfa & Control & Tallow \\
\hline \multicolumn{7}{|c|}{ Weight gain up to 90 days, $\mathrm{kg}$} \\
\hline & 1 & & 27.9 & 31.0 & 29.6 & 28.9 \\
\hline & 2 & & 30.8 & 10.8 & 21.0 & 20.1 \\
\hline & 3 & & 21.1 & 17.4 & 13.2 & 11.6 \\
\hline & & Avgabc & 26.3 & 16.8 & 21.3 & 20.2 \\
\hline \multicolumn{7}{|c|}{ Weight gain 90 to 110 days, $\mathrm{kg}$} \\
\hline & 1 & & 13.2 & 11.6 & 9.6 & 14.9 \\
\hline & 2 & & 10.8 & 11.5 & 12.5 & 10.1 \\
\hline & 3 & & 17.4 & 21.3 & 20.8 & 18.6 \\
\hline & & $A v g{ }^{c d}$ & 13.8 & 14.8 & 14.3 & 14.5 \\
\hline \multicolumn{7}{|c|}{ Lactation weight loss, $\mathrm{kg}$} \\
\hline & 1 & & 3.6 & 4.3 & 5.1 & 2.9 \\
\hline & 2 & & 4.7 & 1.0 & 4.6 & .8 \\
\hline & 3 & & 11.6 & 4.8 & 7.6 & 7.6 \\
\hline & & Avgd & 6.6 & 3.4 & 5.8 & 3.7 \\
\hline \multicolumn{7}{|c|}{ Lactation ADFI, kg } \\
\hline & 1 & & 5.31 & 5.03 & 5.44 & 4.87 \\
\hline & 2 & & 4.98 & 5.04 & 5.12 & 4.91 \\
\hline & 3 & & 4.58 & 5.26 & 5.12 & 4.84 \\
\hline & & Avg be & 4.95 & 5.11 & 5.23 & 4.88 \\
\hline
\end{tabular}

\footnotetext{
${ }^{a}$ Alfalfa effect $(P<.05)$.

${ }^{\mathrm{b}}$ Gestation treatment $X$ cycle interaction $(\mathrm{P}<.05)$.

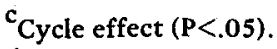

$\mathrm{d}_{\text {Lactation treatment }} X$ cycle interaction $(P<.05)$.

$\mathbf{e}_{\text {Tallow effect }}(\mathrm{P}<.05)$.
} 


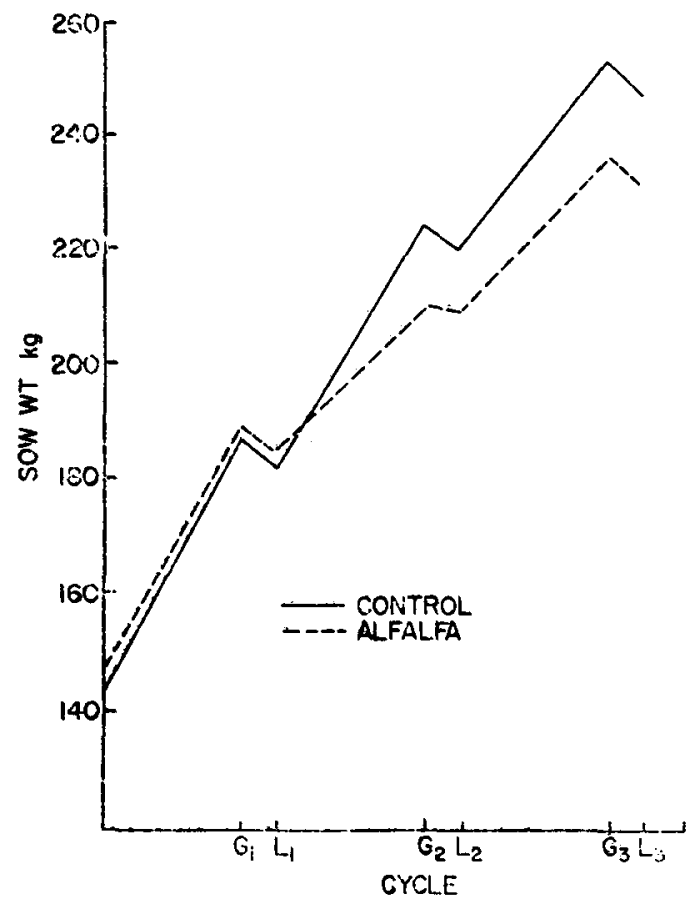

Figure 1. Effect of additions of alfalfa to gestation diets on maternal weight.

controls $(31.0 \mathrm{~kg}$ vs 27.9$)$, whereas in the second and third cycles, sows fed the control diet gained more weight than those fed the alfalfa diet. The lactation diets did not sighificantly affect maternal weight gain from 90 to 110 days of gestation. The major contributing factor to the differences $(\mathrm{P}<.05)$ between treatments in total ( 0 to 110 days of gestation) maternal gain was the gestation diets. Several researchers (Bowland, 1967, Esley, 1968; Lodge, 1969; Frobish et al., 1973; Líbal and Wahlstrom, 1977) have observed that maternal weight gain is a function of caloric intake.

Weight loss during lactation was hot significantly affected by the addition of alfalfa to diets during gestation or of tallow to diets during lactation.

Average daily feed intake (ADFI) during lactation was lower $(P<.05)$ for the tallow-supplemented group (4.88 is $5.23 \mathrm{~kg}$ ) because of the increased caloric density of the diet. Other researchers (Cast et al., 1977; Allee and Salava, 1978; Boyd et al, 1978, 1979) have observed a reduction in ADFI of approximately 7\% during lactation for animals fed diets supplemented with 8 to $12 \%$ tallow.

The effect of the dietary additions of alfalfa
TABLE 5. EFFECT OF DIETARY ADDITIONS OF ALFALFA AND TALLOW ON GESTATION INTERVAL

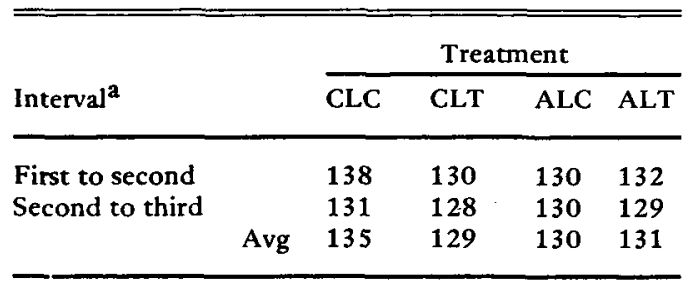

Average number of days from weaning until next farrowing.

and tallow on gestation interval is shown in table 5. Gestation interval was defined as the average number of days from weaning until next farrowing. Gestation interval, an indication of conception rate, was not significantly affected by the treatments. Moser (1978) and Teague (1955) suggested that the inclusion of alfalfa in gestation diets may help increase conception rate because of the estrogenic activity of alfalfa.

\section{Literature Cited}

Allee, G. L. 1977. Using dehydrated alfalfa to control intake of self-fed sows during gestation. Feedstuffs 49:20.

Allee, G. L. and J. Salava. 1978. Effect of adding fat to diets during late gestation and lactation. Kansas State Agr. Exp. Sta. Rep. 342, p. 29.

Bowland, J. P. 1967. Energetic efficiency of the sow. J. Anim. Sci. 26: 553.

Boyd, R. D., B. D. Moser, E. R. Peo, Jr. and P. J. Cunningham. 1978. Effect of energy source prior to parturition and during lactation on milk lipids, pigiet survival and growth. J. Anim. Sci. 47:883.

Boyd, R. D., B. D. Moser, E. R. Peo, Jr. and A. J. Lewis. 1979. Effect of tallow and choline chloride supplementation prior to parturition and during lactation on pig survival and growth. J. Anim. Sci. 49(Suppl. 1):236.

Cast, W. R., B. D. Moser, E. R. Peo, Jr. and P. J. Cunningham. 1977. Fat, choline and thyroprotein additions to the diet of lactating swine. J. Anim. Sci. 45:80 (Abstr.).

Conover, W. J. 1971. Practical Nonparametric Statistics. John Wiley and Sons, Inc,, New York.

Danielson, D. M. and J. J. Noonan. 1975. Roughages in swine gestation diets. J. Anim. Sci. 41:94.

Esley, F.W.H. 1968. The influence of feeding level upon the reproductive performance of pregnant sows. Vet. Rec. 83:93.

Frobish, L. T., N. C. Steele and R. J. Davey. 1973. Long term effect of energy intake on reproductive performance of swine. J. Anim. Sci. 36:293.

Harvey, W. R. 1960. Least-squares analysis of data with unequal subclass numbers. USDA, ARS 20-8.

Libal, G. W. and R. C. Wahlstrom. 1977. Effect of 
gestation metabolizable energy levels on sow productivity. J. Anim. Sci. 45:286.

Lodge, G. A. 1969. The effects of pattern of feed distribution during the reproductive cycle on the performance of sows. Anim. Prod. 11:133.

Moser, B. D. 1978. Perennial forages for sows. Ontario Forage Conf. Toronto.

Peo, E. R., Jr. 1975. Hay reduces sow feed cost. Swine Information Service. National Hog Farmer Bull. E9.

Pollman, D. S. and D. M. Danielson. 1978. Limitedinterval feeding of alfalfa. Nebraska Swine Rep. EC 78-219, p. 19.

Pollmann, D. S., D. M. Danielson and E. R. Peo, Jr. 1978. Effect of dietary roughage on reproductive performance and hematology of sows. Proc. Western Sec. ASAS 29:197.

Pollmann, D. S., D. M. Danielson and E. R. Peo, Jr. 1979. Value of high fiber diets for gravid swine. J. Anim. Sci. 48:1385.

Seerley, R. W., R. A. Pace, C. W. Foley, and R. D. Scarth. 1974. Effect of energy intake prior to parturition on milk lipids and survival rate, thermostability and carcass composition of piglets. J. Anim. Sci. 38:64.

Seerley, R. W. and R. C. Wahlstrom, 1963. South Dakota State College, A. S. Mimeo, Series 63:4.

Teague, H. S. 1955. The influence of alfalfa on ovulation rate and other reproductive phenomena in gilts. J. Anim. Sci. 14:621. 